\title{
Social Support Moderating Effect between Work-Family Conflict and Working Students' Health and Stress in UPSI
}

\author{
Ahmad Zainal Abidin Abd Razak ${ }^{\mathrm{a}}$, Nek Kamal Yeop Yunus ${ }^{\mathrm{b}}$, Norsamsinar Samsudin ${ }^{\mathrm{c}}$, \\ Hariyaty Ab Wahid ${ }^{\mathrm{d}}$, Zaiton Wahid \\ a,b,c,d Faculty of Management and Economics, Universiti Pendidikan Sultan Idris, Malaysia, \\ ${ }^{\mathrm{e}}$ Faculty of Education, Universiti Kebangsaan Malaysia, Malaysia, \\ Correspondence author: ahmad.zainal@fpe.upsi.edu.my
}

DOI: https://doi.org/10.37134/ibej.vol12.3.2019

\begin{abstract}
Many studies have been done in addressing work-family conflict (WFC) among employees working in organizations. Thus, the focus of this study is to address WFC that has been faced by currently working and studying adults, and examine its relationship with their health and stress condition. In addition, this study examines the moderating effect of social support between WFC and working student's health and stress condition. The sample for this study consists of working students enrolling in part-time programs in Universiti Pendidikan Sultan Idris, Malaysia. Questionnaires were distributed to students pursuing part-time programs in Universiti Pendidikan Sultan Idris. The questionnaire was developed based on past literature and proposed research framework. The questionnaire comprised of questions regarding WFC, stress, health, social support and demographic questions. Findings from the research indicated that WFC, faced by working students in UPSI, were significantly related to stress, health, and social support. As for the moderation effect, this study found that social support significantly moderated the relationship between WFC and working students' stress condition, but not with health. Suggestions on actions needed to be constructed in unravelling WFC matters among working students. Policies and plans on how to mitigate WFC were suggested. Such suggestions might benefit policymakers and government in introducing relevant initiatives so that working adults' special needs could be fulfilled, consequently reduced WFC faced by them.
\end{abstract}

\section{Keywords:}

Health, Social Support, Stress, Work-family Conflict (WFC) and Working Students.

\section{INTRODUCTION}

Attention given by present-day society on both work and non-work life relationships has surged significantly (Gao, Shi, Niu \& Wang, 2013; Montgomery, Panagopolou \& Benos, 2006). Conventional family setting, encompassing fathers, mothers and children over the years have been transformed into new dimensions. Now, the roles of women, who were once associated to be the persons dealing with home issues (Weiss, 1990), and men, who were portrayed as head of the families and became the bread-winners of the families, devoted their effort on their work (Kanter, 1977), have transformed entirely into a variety of different family arrangement. Housework chores and caring for children responsibilities, are no longer restricted to women, they are now the responsibilities commonly shared by both genders (Carnicer et al., 2004). Since both genders have equal tasks and responsibilities, at home and the workplace, they build pressures on both genders to perform equally well at the workplace and at home, which lead to work-family conflict (WFC) (Posig \& Kickul, 2004). Often, when individuals are inclined to overcome WFC, they tend to seek out support, either emotionally or practically, via informal and formal means. This is known as "social support". According to Wadsworth (2003), social support sources, include support from superiors, co-workers, families, and friends, have been proven to decrease WFC incidents by individuals (Lin, 2008). 


\section{PROBLEM STATEMENT}

Malaysian Higher Education has always benefitted from the highest allocation in the national development budget annually. Over the years, Malaysian tertiary education has expanded with increasing number of public or private universities, local or foreign-owned, university colleges, colleges and others. There have been fierce competition, thus forcing these higher learning institutions to offer extensive range of tertiary qualifications at reasonable prices. The eminence of tertiary education has been acknowledged by the Malaysian government where five universities, out of the 20 public universities, have been ascribed as research university status. Because of this, additional funding for research and development and commercialization have been allocated. The remaining 15 public universities have been ascribed as either comprehensive or focus universities. The establishment of these universities are intended to accommodate, approximately its 30 million multi-ethnic populations, and encourage foreign students pursuing tertiary education in Malaysia.

Malaysian society has recognized and acknowledged lifelong learning as one of the means to ensure talent development. In fact, lifelong learning has been embedded as one of the key pillars in the Malaysian Education Blueprint 2015-2025. To achieve this, the Ministry of Higher Education (MOHE) has initiated flexible-education opportunities to allow working adults to pursue their education which aims to create a culture of a "Nation of Lifelong Learners". Even before the set up of Malaysian Education Blueprint, educational institutions worldwide, including in Malaysia, have constantly placed immense importance on inspiring working adults to continue their studies. Since the introduction of Malaysian Education Blueprint 2013-2025, a large number of local and foreign universities, university colleges and colleges, have increased in numbers, offering wide-ranging academic programs at various levels and disciplines to satisfy the interests of these working adults. The programs offered, range from full-time studies, attending classes on daily or weekly or monthly or online or mixtures or other approaches.

The advancement in software and hardware technology has tremendously improved the learning experience of these working adults. It is observed that the expansion of education can be done easily. In one hand, the students found that managing their work schedule and study as very challenging, on the other hand, they might find them to be different. They used to have lots of worries on work and learning simultaneously, plus the need to balance them with their responsibilities as spouses or parents. Lack of management skill among students further heightened their stress level (Hamizatun Akmal \& Norzaini, 2013). Eventually, some students decided to withdraw from their studies and in worst scenario, some marriages were threatened, which had brought negative implication to the nation. Thus, it is important to recognize the effect of these conflicts so that solutions to alleviate the effect either on the study, work or family can be initiated. This research examines the significant steps to be adopted to understand the social support moderating effect on WFC and health and stress of working students in Universiti Pendidikan Sultan Idris (UPSI).

\section{LITERATURE REVIEW}

\section{Conflict Theory}

Karatepe and Baddar (2006), and Frone, Yardley, \& Markel (1997) suggested that there were two different but linked constructs in WFC; first, Work Interference with Family (WIF) and second, Family Interference with Work (FIW) which originated from conflict theory (Byron, 2005). According to Greenhaus and Beutell (1985), work and family sphere conflicted 
between each other due to their different norms and concerns. The conflicting norms and concerns of work and family had triggered disturbance and destructive outcome on both work and family spheres, which often referred to as WFC. Kahn et al. (1964) termed WFC as an inter-role type of conflict in which burdens from the work sphere, contradicted with the burdens from the family sphere. Consequently, individuals having extra roles, combined with limited resources of time and energy, had created strain between opposing demands which caused a feeling of burden and role clashes (Fu \& Shaffer, 2001).

\section{Work-Family Conflict}

WFC as defined by Greenhaus and Beutell (1985) is "a form of inter-role conflict in which role pressures from work and family domains are mutually incompatible in some respect". The situation may arise when one's role as family (e.g.: father) interferes with another work role (e.g.: employee). This situation is known as "work-family conflict". Greenhaus and Beutell (1985) further elaborate, if a person allocates extra time and effort into one role, irrespective of work role or family role, another role which the person allocates less time and effort is expected to suffer. Past researches acknowledged that WFC had mutual relationship in nature. This led to diverse emotional and physical outcome on people (Adams et al., 1996; Lieter \& Durup, 1996). Normally, the public reported higher WIF than FIW (Frone et al., 1992; Kinnunen \& Mauno, 1998). Past studies showed that WFC did not only disturbed the ability of people to cope with family and work responsibilities (Ollier-Malaterre et al., 2013) and child rearing (Zhang et, al. 2012), but also with work performance (Adams et al., 1996; Boles, Howard \& Donofrio, 2001; Nart \& Batur, 2013), stress and mental strain (Allen, Herst, Bruck, \& Sutton, 2000), and escalated the threat of grave and prolonged psychological and physical health complications (Frone, Russell, \& Cooper, 1997; Greenhaus et al., 2006).

\section{Social Support and Work Family Conflict}

Previous social support research findings showed that relief among persons were amplified when the amount of social support they obtained was increased (Cort et al., 2014; Lakey \& Cohen, 2000). According to Wadsworth (2003), social support sources included support from supervisors, colleagues, relatives, spouse and friends which had proven to reduce WFC (Lin, 2008). Supports might be in terms of assistance, advice, understanding (Aycan \& Eskin, 2005) or emotional and instrumental support (Adams, King, \& King, 1996). Aycan and Eskin (2005) further explained the meaning of supports as complete understanding and paying attention, the declaration of love, guidance, genuine concern for personal wellbeing and solid assistance with errands and childcare. The definition was further supported by studies done by previous researchers. Selvarajan et al (2016) and Stoner et al.(1990), for instance, emphasized the positive result of social support on WFC. The more supports a person received, the lower the inclination for such person to suffer from WFC (Ford et al.; 2007), work stress (Aryee et al., 1999; Thomas \& Ganster, 1995), impaired well-being and job attitudes (Allen et al., 2000) and deteriorated work and health, wellbeing and stress (Nabavi \& Shahriari, 2012). However, according to Dormann \& Zapf (1999), WFC studies using social support as moderator was still lacking.

\section{Stress and Work-Family Conflict}

Previous studies have revealed that stress and psychological strain are two major outcomes of WFC (Kossek \& Ozeki, 1998; Netemeyer et al., 1996). The higher a person experiences WFC, the higher his or her level of stress (Adams et al., 1996; Kelly \& Voydanoff, 1985). 
Empirical evidence also acknowledges that WFC is often the source of stress at work, leading to various negative outcomes, such as poor job attitudes and deteriorated well-being (Kossek \& Ozeki, 1998).

\section{Health and Work-Family Conflict}

There have been many studies, associating family care and paid work, done in the $21 \mathrm{st}$ century. According to Davis et al., (2016), the greatest obvious settings for adult well-being and growth are work and family. Yet, few researches had been done to study the effects of health, work-family mismatch and stress. The assortments of work and family structures, and the upsurge of dual couple involvement had created a controversial public policy issues (Bianchi \& Milkie, 2010). The issues ranged from individual health and well-being as the result of paid family and work life, (Bianchi \& Milkie, 2010), erratic working time caused WFC, which led to poor health, greater depression level and stressful level (Barnett et al., 2008; Perry Jenkins et al., 2007; Barnett \& Gareis, 2006). Changes in the characteristics of the nature of work including lengthened travel times, advancement in technology that made employees' accessibility around the clock, performing work at non-standard times, and limited social support contributed to WFC and poor health of workers (Davis, Gere \& Sliwinski, 2017). Furthermore, employees that experienced higher WFC, received lesser family and work support had a tendency to have greater psychological and physical health problems. In terms of psychological health, the WFC caused life dissatisfaction, mental distress, depressing indicators, and apprehension (Amstad, Meier, Fasel, Elfring \& Semmer, 2011; Greenhaus et al., 2006).

\section{CONCEPTUAL FRAMEWORK}

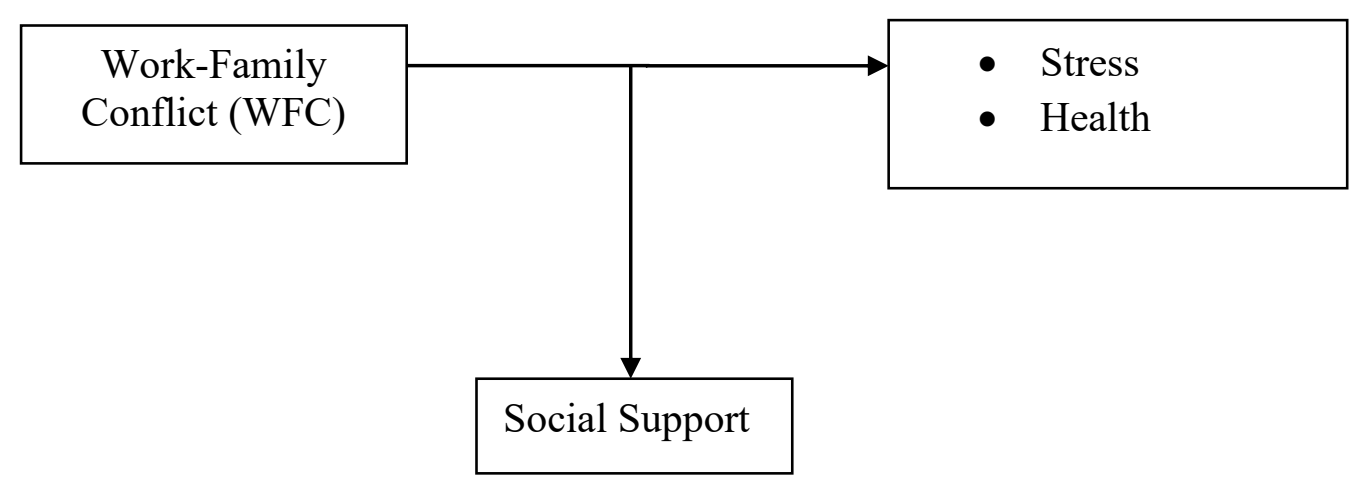

Figure 1: Conceptual framework

The above proposed conceptual framework shown in Figure 1 revealed the relationship between WFC as independent variables (IV) and stress and health as dependent variables (DV), while social support serves as the moderating variable in this study. The framework was adapted from the basic Conflict Theory (Byron, 2005).

\section{METHODOLOGY}

The current study conducted, was a correlational study, where the primary objective was to investigate social support, WFC, health and stress relationship of working students in UPSI. This study involved current students pursuing their studies in UPSI and conducted in a non- 
contrived setting. Self-administered questionnaires were used to collect data regarding the study.

The population for this study consisted of full time working students, who currently studying part time in UPSI. The unit of analysis for this study was the individual (Sekaran, 2006). The number of working students' population was approximately 5,029 persons. The list of students comprising the total numbers of students, name, contact number and email address and its breakdown was obtained from the Institute of Graduate Studies and Centre for Enhancement of Knowledge and Professional Studies (CEKAPS), UPSI. The study adopted a cross-sectional research design. For this study, systematic sampling was used to collect the data. A total of 400 questionnaires were distributed to UPSI students who were studying and working. The questionnaires were randomly distributed to the students, accompanied with a letter from the researchers to respondents, indicating the intention of the study, confidentiality, anonymity and instructions on how to answer the questionnaires. Out of 400 distributed questionnaires, a total of 297 questionnaires were returned, yielding a response rate of $74.25 \%$. Out of these, 57 questionnaires were found to be unusable. The questionnaires were found unusable because the questionnaires were either incompletely filled or the respondents did not fulfil the criteria as determined by researchers. Finally, only 240 questionnaires were acceptable and used in the study. The 240 questionnaires were coded and analyzed.

Table 1: Summaries of measurement and reliability coefficients variables for the study variables

\begin{tabular}{|c|c|c|c|c|}
\hline Author/s and Year & $\begin{array}{l}\text { No of } \\
\text { Items }\end{array}$ & Measuring & $\begin{array}{l}\text { Cronbach } \\
\text { alpha past } \\
\text { study }\end{array}$ & $\begin{array}{c}\text { Cronbach } \\
\text { alpha current } \\
\text { study }\end{array}$ \\
\hline \multirow[t]{2}{*}{ Netemeyer et.al (1996) } & Five & Work Interference with Family & 0.94 & 0.92 \\
\hline & Five & $\begin{array}{l}\text { Family Interference with Work } \\
\text { Combine }\end{array}$ & 0.87 & $\begin{array}{l}0.92 \\
0.93\end{array}$ \\
\hline $\begin{array}{l}\text { Cohen, Mermelstein, } \\
\text { Kamarck and Hoberman } \\
\text { (1985) }\end{array}$ & Ten & Social Support & 0.84 & 0.61 \\
\hline $\begin{array}{l}\text { Cohen, Kamarck, and } \\
\text { Mermelstein (1983). }\end{array}$ & Four & Stress & 0.86 & 0.87 \\
\hline $\begin{array}{l}\text { Davies, Sherbourne, } \\
\text { Peterson and Ware } \\
\text { (1988) }\end{array}$ & $\begin{array}{l}\text { Thirty } \\
\text { Two }\end{array}$ & Health & 0.90 & 0.76 \\
\hline
\end{tabular}

The respondents were asked about the variables used in this study. As for the WIF and FIW, the questionnaire developed by Netemeyer et al. (1996) was adapted to measure WIF and FIW. All items were measured on a 6-point Likert scale ranging from (1) strongly disagree to (6) strongly agree. As for social support, ten items were asked using an instrument adapted from Cohen, Mermelstein, Kamarck and Hoberman (1985), Appraisal Support measures. Stress was measured using the Perceived Stress Scale (PSS), a ten-item scale instrument adapted from Cohen, Kamarck, and Mermelstein (1983). For PSS, all items were measured on a 6-point Likert scales ranging from (1) never to (6) very often. Finally, health was measured using a thirty-two item instrument adapted from the study conducted by Davies, Sherbourne, Peterson and Ware (1988). All items concerning health were measured on a 6-point Likert scale ranging from (1) definitely false to (6) definitely true. Refer to table 1. 


\section{DATA ANALYSIS}

As shown in Table 1, the Cronbach's alpha for all variables in this study was in the range of .60 to .93 . The reliability for WFC, and health and stress, had reliability coefficients above .70 , respectively, and could be considered good (Sekaran, 2006). Only one variable, which was the social support variable, had a reliability coefficient below .70 that was .61 . Generally, a value of Cronbach's alpha is .70 is the minimum acceptable lower limit, however a value of .60 can be accepted in an exploratory research (Hair et al, 2006). Therefore, the social support variable was accepted.

Table 2: Profile of Respondents

\begin{tabular}{llcc}
\hline \multicolumn{1}{c}{$\begin{array}{c}\text { Demographic } \\
\text { Variables }\end{array}$} & \multicolumn{1}{c}{ Categories } & Frequency & Percentage \\
\hline Gender & Male & 101 & 42.3 \\
& Female & 138 & 57.7 \\
\hline Marital Status & Married & 170 & 70.8 \\
& Single & 65 & 27.1 \\
& Divorced & 5 & 2.1 \\
\hline Nationality & Malaysian & 224 & 93.3 \\
& Non Malaysian & 15 & 6.3 \\
\hline Race & Malay & 181 & 75.4 \\
& Chinese & 13 & 5.4 \\
& Indian & 31 & 12.9 \\
& Others & 15 & 6.3 \\
\hline Education & Master's Degree & 185 & 27.9 \\
& Ph.D or equivalent & 55 & 71.7 \\
\hline Mode of Study & Full Time & 67 & 5.6 \\
& Part Time & 172 & 51.4 \\
\hline Position & Managerial & 87 & 36.4 \\
& Non Managerial & 152 & 63.6 \\
\hline
\end{tabular}

Note: $\quad N=240$

The respondents were asked to answers questions about their gender, marital status, nationality, ethnicity (race), educational level, mode of study and position held at the work place. The breakdown was shown in Table 2. A Pearson's correlation coefficients (r) were computed to examine the strength and direction of the relationship (Cavana, Delahaye \& Sekaran, 2000). This study used the Pearson correlation coefficient (r) to determine the strength and direction of the relationship among the variables studied. Before conducting the correlation analysis, test were carried out to ensure that no violation of the assumptions of linearity, normality and homoscedasticity. It was found that, no violations of the assumptions were discovered. Correlation coefficients of .10, .30, .50 irrespective of the sign in behavioral sciences, were normally inferred as small, medium, and large coefficients (Green, Salkind \& Akey, 1997). Multicollinearity is said to occur if the result shows a correlation exceeding .90 (Hair et al., 2006).

According to Rasli (2006), some researchers did not know how to interpret correlation output. Rasli (2006) added that the intercorrelation should focus on the main theme of the study, which was WFC (WIF and FIW). As such, this study focused on reporting the correlation between WIF variable and the independent variables which were, stress, health and social support as shown in Table 3. Correlations among the variables studied were statistically significant, ranging from $r=-.139(p<.05)$ to $r=.369(p<.01)$. Correlations between WFC and Social Support were statistically significant, $r=.369(p<.01)$, WFC and 
stress were statistically significant, $\mathrm{r}=.220(\mathrm{p}<.01)$, and WFC and health were statistically significant, $r=.269(\mathrm{p}<.01)$.

Table 3: Pearson correlations matrix for work-family conflict, job performance, stress, burnout, health and social support

\begin{tabular}{|c|c|c|c|c|c|c|c|}
\hline \multicolumn{8}{|c|}{ Correlations } \\
\hline & & WFC & JobPer & Stress & Burnout & Health & SoSupport \\
\hline \multirow[t]{3}{*}{ WFC } & Pearson Correlation & 1 & $-.139^{*}$ & $.220^{* *}$ & $.300^{* *}$ & $.269^{* *}$ & $.369^{* *}$ \\
\hline & Sig. (2-tailed) & & .031 & .001 & .000 & .000 & .000 \\
\hline & $\mathrm{N}$ & 240 & 240 & 240 & 240 & 240 & 240 \\
\hline \multirow[t]{3}{*}{ JobPer } & Pearson Correlation & $-.139^{*}$ & 1 & .098 & .062 & .053 & .109 \\
\hline & Sig. (2-tailed) & .031 & & .129 & .336 & .415 & .092 \\
\hline & $\mathrm{N}$ & 240 & 240 & 240 & 240 & 240 & 240 \\
\hline \multirow[t]{3}{*}{ Stress } & Pearson Correlation & $.220 * *$ & .098 & 1 & $.363^{* *}$ & $.262^{* *}$ & .120 \\
\hline & Sig. (2-tailed) & .001 & .129 & & .000 & .000 & .063 \\
\hline & $\mathrm{N}$ & 240 & 240 & 240 & 240 & 240 & 240 \\
\hline \multirow[t]{3}{*}{ Burnout } & Pearson Correlation & $.300 * *$ & .062 & $.363^{* *}$ & 1 & $.167^{* *}$ & $.241^{* *}$ \\
\hline & Sig. (2-tailed) & .000 & .336 & .000 & & .009 & .000 \\
\hline & $\mathrm{N}$ & 240 & 240 & 240 & 240 & 240 & 240 \\
\hline \multirow[t]{3}{*}{ Health } & Pearson Correlation & $.269 * *$ & .053 & $.262^{* *}$ & $.167^{* *}$ & 1 & $.380^{* *}$ \\
\hline & Sig. (2-tailed) & .000 & .415 & .000 & .009 & & .000 \\
\hline & $\mathrm{N}$ & 240 & 240 & 240 & 240 & 240 & 240 \\
\hline \multirow[t]{3}{*}{ SoSupport } & Pearson Correlation & $.369 * *$ & .109 & .120 & $.241^{* *}$ & $.380 * *$ & 1 \\
\hline & Sig. (2-tailed) & .000 & .092 & .063 & .000 & .000 & \\
\hline & $\mathrm{N}$ & 240 & 240 & 240 & 240 & 240 & 240 \\
\hline
\end{tabular}

*. Correlation is significant at the 0.05 level (2-tailed).

**. Correlation is significant at the 0.01 level (2-tailed).

Based on Table 3, all five (5) intercorrelations were statistically significant. Most of the correlations among variables were significant. The strength of the correlations was below .90 , indicating no serious multicollinearity issue (Hair et al., 2006). To test the moderating effect, we adopted the method used by Baron and Kenny (1986) using hierarchical regression analysis. The hierarchical regression analysis was the most appropriate method for investigating interaction effects as suggested by Aiken and West (1991), thus the method was applied. This method was also used to examine the main and interacting effects of WFC on the dependent variables which were health and stress. Then, an independent test using social support were included, as a moderating relationship between WFC and stress. Similar to prior research, this study used age and marital status as control variables because these two variables were closely related to WFC (Hsu, 2011, Wang \& Tsai, 2014). WFC was then entered, followed by social support and the interaction variables. Observing a significant amount of variance in the final step would indicate a moderating relationship between WFC and the variables studied.

To test the moderating effect on stress was a result of a WFC, and more specifically whether social support moderated the relationship between WFC and stress, a hierarchical multiple regression analysis was conducted. In the first step, two variables were included: stress and social support. These variables accounted for a significant amount of variance in stress, $\mathrm{R}^{2}=.050, \mathrm{~F}(2,237)=6.234, \mathrm{p}<.005$. To avoid potentially problematic high multicollinearity with the interaction term, the variables were entered and an interaction term between stress and social support was created (Aiken \& West, 1991). Next, the interaction term between stress and social support was added to the regression model, which accounted for a significant proportion of the variance in stress, $\Delta \mathrm{R} 2=.085, \Delta \mathrm{F}(3,236)=7.305, \mathrm{p}=$ 
$.001, b=.147, p<.05$. It can be concluded that the relationship between WFC and stress is moderated by social support. Thus, the hypothesis is rejected.

Table 4: Results of hierarchical regression of work-family conflict (work interference with family and family interference with work) effect on stress

\begin{tabular}{lll}
\hline Predictors & $\begin{array}{l}\text { Model 1 } \\
\text { Std. B }\end{array}$ & $\begin{array}{l}\text { Model 2 } \\
\text { Std. B }\end{array}$ \\
\hline Step 1: Control Variables & & \\
Age & -.11 & -.10 \\
Marital Status & .06 & .09 \\
Step 2: Work-Family Conflict & & \\
WFC & & $.288^{* *}$ \\
& & \\
\hline F value & 2.428 & 6.004 \\
$\mathrm{R}^{2}$ & .02 & .07 \\
Adjusted $\mathrm{R}^{2}$ & .01 & .06 \\
$\mathrm{R}^{2}$ Change & .02 & .05 \\
F-Change & 2.428 & $12.911^{* *}$ \\
\hline${ }^{*} \mathrm{p}<0.05,{ }^{* *} \mathrm{p}<0.01 ;$ Dependent: Stress & &
\end{tabular}

To test the moderating effect on health was a result of the WFC, and more specifically whether social support moderated the relationship between WFC and health, a hierarchical multiple regression analysis was conducted. In the first step, two variables were included: health and social support. These variables accounted for a significant amount of variance in health, $\mathrm{R}^{2}=.164, \mathrm{~F}(2,237)=23.183, \mathrm{p}<.001$. To avoid potentially problematic high multicollinearity with the interaction term, the variables were entered and an interaction term between health and social support was created (Aiken \& West, 1991). Next, the interaction term between health and social support was added to the regression model, which accounted for a significant proportion of the variance in health, $\Delta \mathrm{R} 2=.170, \Delta \mathrm{F}(3,236)=16.133, \mathrm{p}=$ $.001, \mathrm{~b}=.037, \mathrm{p}>.05$. It can be concluded that the relationship between WFC and health is not moderated by social support. Thus, the study failed to reject the hypothesis.

Table 5: Results of hierarchical regression of work-family conflict (work interference with family and family interference with work) effect on health

\begin{tabular}{lll}
\hline Predictors & $\begin{array}{l}\text { Model 1 } \\
\text { Std. B }\end{array}$ & $\begin{array}{l}\text { Model 2 } \\
\text { Std. B }\end{array}$ \\
\hline Step 1: Control Variables & & \\
Age & .13 & $.14^{*}$ \\
Marital Status & .07 & .11 \\
Step 2: Work-Family Conflict & & \\
WFC & & $.283^{* *}$ \\
\hline F value & 1.921 & 8.194 \\
$\mathrm{R}^{2}$ & .02 & .10 \\
Adjusted ${ }^{2}$ & .01 & .08 \\
$\mathrm{R}^{2}$ Change & .02 & .08 \\
$\mathrm{~F}^{2}$ Change & 1.921 & $20.42^{* *}$ \\
\hline${ }^{*} \mathrm{p}<0.05,{ }^{* *} \mathrm{p}<0.01 ;$ Dependent: Health & &
\end{tabular}




\section{DISCUSSION}

From the regression results, social support significantly moderated the relationship between WFC and working students stress condition. The findings from this study were consistent with past studies associated with social support (Aryee et al., 1999 \& Viswesvaran et al., 1999). A plausible reason is that the respondents for this study are working students; they themselves need to overcome stress resulting from their decision to simultaneously pursue their studies, work and become effective family members. Thus, having people who can help with house chores, taking care of parents or children, colleagues who are willing to help with work or study, occasionally can reduce stress. The social support can vary according to age, marital status and a number of children. The regression results also indicated that social support did not significantly moderate the relationship between WFC and working student's health condition. The finding from this study was consistent with past studies associated with social support (Carlson \& Perrewe, 1999; Parasuraman et al., 1992). A plausible reason is that the respondent in this study are working adults and can be considered quite financially strong, whereby poorer health is often associated to lesser socioeconomic groups (Stansfeld et al. 2003). As for the moderation effect, social support on health by social class may be due to dissimilarities in susceptibility (Gruenewald \& Seeman, 2010). In this study, all respondents are working, financially stable, and perhaps, the organizations, they are working for, do provide healthcare facilities to keep them fit and healthy.

\section{THEORETICAL AND PRACTICAL IMPLICATIONS}

This study also provides some empirical support in the area of WFC among working adults pursuing tertiary education since only few studies concerning such issues have been carried out in Malaysia. From the results, two observations emerged. First, one can understand the direct effect of WFC on health and stress of working students in UPSI. Second, one can also comprehend the moderating effect of social support between WFC and health and stress of working students in UPSI. This study is important in understanding the effect of WFCs on working adults. The nation and the students, in particular, have spent a lot of resources such as money, energy and time, and have make sacrifices to enhance their qualification. However, due to their commitment to work and family, some of them may not be able to achieve their goals. Top management of UPSI and policymakers may make use of the findings to solve WFC issues among working students. Policies and plans will be recommended so that UPSI, policymakers and government initiatives can be done effectively suitable with their special needs. This is important, not only for the working students' sake but for the growth of the nation as well.

\section{LIMITATIONS AND SUGGESTIONS FOR FUTURE STUDIES}

Several limitations of the study were identified. First, the dependent variables that affected WFC were limited in scope. Only limited work outcomes were investigated, whereas many other non-work-related outcomes (family performance, life/marital/family satisfaction) and stress-related outcomes (work-family stress and family-related stress, general mental strain, physical stress, depression, substance abuse) were not included in the study. Future research may need to broaden the range of study by incorporating these variables.

Second, this study was limited to students studying in UPSI. Larger samples, involving other higher learning institutions, are needed, where similar research could be duplicated. Using larger samples within the same industry or occupations will improve the generalization of the findings. 
Finally, since this research was a cross-sectional study, it restricted the study's ability to prove a cause-effect relationship (Sekaran, 2000). Thus, a longitudinal research is recommended where it will help validate the findings from cross-sectional surveys since human behaviors, perception, attitudes and needs are likely to change over time.

\section{CONCLUSION}

This study has examined a model of social support moderating effect between WFC and health and stress of working students in UPSI. It provides some empirical support to the theoretical framework that links the WFC studies. Hence, it is important for UPSI administrators and the Malaysian Ministry of Education to address the issue of WFC among working adults, in pursuing their tertiary education. Attempts should be made to solve issues such as health and stress, and the impact of social support on working adults pursuing tertiary education. Should the issue be left unattended, most probably the initiatives by the Malaysian government to create a "Nation of Lifelong Learners" will not be accomplished.

\section{ACKNOWLEDGEMENT}

This paper is based on the research project entitled The Moderating Effect of Social Support Between Work Family Conflict and Health, Stress, Burnout and Job Performance of Working Students In UPSI. The authors would like to extend their gratitude to the Research Management and Innovation Centre (RMIC), Sultan Idris Education University (UPSI) for the University Research Grants (code: 2017-0105-106-1 - GGPU) that helped fund the research.

\section{REFERENCES}

Aiken, L. S., \& West, S. (1991). Multiple regression: Testing and interpreting interaction. Thousand Oaks, CA: Sage.

Adams, G. A., King, L. A., \& King, D. W. (1996). Relationships of job and family involvement, family social support, and work-family conflict with job and life satisfaction. Journal of Applied Psychology, 81, 411-420.

Allen, T.D., Herst, D.E.L., Bruck, C. \& Sutton, M. (2000). Consequences associated with work-to-family conflict: A review and agenda for future research. Journal of Occupational Health Psychology, 5(2), 278-308.

Amstad, F. T., Meier, L.L., Fasel. U., Elfring. A., \& Semmer, N.K. (2011). A meta-analysis of work family conflict and various outcomes with a special emphasis on cross domain versus matching domain relations. Journal of Occupational Health Psychology, 16, 151-169.

Andreassi, J. K., \& Thompson, C. A. (2007). Dispositional and situational sources of control: Relative impact on work-family conflict and positive spillover. Journal of Managerial Psychology, 22(8), 722Y740. doi:10.1108/02683940710837697

Aycan, Z. \& Eskin.M, (2005). Relative contributions of childcare, spousal support, and organizational support in reducing work-family conflict for men and women: The case of Turkey, Sex Roles, 53, 453-471.

Barnett, R. C., Gareis, K.C., \& Brennan, R. T. (2008). Wives' shift work schedules and husbands' and wives' well-being in dual-earner couples with children: A withincouple analysis. Journal of Family Issues, 29, 396-422.

Barnett, R.C. \& Gareis, K. C. (2006). Parental after-school stress and psychological wellbeing. Journal of Marriage and Family, 68, 101-108. 
Baron, R. M., \& Kenny, D. A. (1986). The moderator-mediator variable distinction in social psychological research: Conceptual, strategic, and statistical considerations. Journal of Personality and Social Psychology, 51(6), 1173 Y1182. doi:10.1037/00223514.51.6.1173

Bedeian,A.,Mossholder, K.\& Touliatos, J. (1986). "Individual propensities for emotional supportiveness within dual-career context: work and non-work reactions", International Journal of Manpower, 7 (4), 7-12.

Bianchi, S. M. and Milkie, M. A. (2010), Work and Family Research in the First Decade of the 21st Century. Journal of Marriage and Family, 72, 705-725. doi:10.1111/j.17413737.2010.00726.x

Boles, J. S., Howard, W. G., \& Donofrio, H. H. (2001). An investigation into the interrelationships of work- family conflict, family-work conflict and work satisfaction. Journal of Managerial Issues, 13(3), 376-390

Boles, J. S., Johnston, M. W., \& Hair, J. F., Jr. (1997). Role stress, work-family conflict and emotional exhaustion: Inter-relationships and effects on some work-related consequences. Journal of Personal Selling \& Sales Management, 17(1), 17-28.

Burke, R.J., \& El-Kot, E.G. (2010). Correlates of work-family conflicts among managers in Egypt. International Journal of Islamic and Middle Eastern Finance and Management, 3(2), 113-131.

Byron, K.,( 2005). A meta-analytic review of work-family conflict and its antecedents, Journal of Vocational Behavior, 67, 169-198.

Carlson, D., \& Perrewe, P. (1999). "The role of social support in the stressor-strain relationship: an examination of work-family conflict", Journal of Management, 25(4), 513-40.

Carnicer, M.P.D.L., Sanchez, A. M. , Perez, M. P., \& Jimenez, M. J. (2004). Work-family conflict in southern European country: The influence of job-related and non-related factors. Journal of Managerial Psychology, 19, 466-489.

Cavana, R.Y, Delahaye, B.L. \& Sekaran,U. (2000). Applied Business Research: Qualitative and Quantitative Methods, John Wiley \& Sons, Inc

Cohen, S., Kamarck, T., and Mermelstein, R. (1983). A global measure of perceived stress. Journal of Health and Social Behavior, 24, 386-396.

Cohen, S., Mermelstein, R., Kamarck, T., \& Hoberman, H. (1985). Measuring the functional components of social support. In I. G. Sarason \& B. Sarason (Eds.), Social support: Theory, research and applications (pp. 73-94). The Hague, The Netherlands: Martinus Nijhoff

Cort W. Rudolph, Jesse S. Michel, Michael B. Harari, Tyler J. Stout, (2014) "Perceived social support and work- family conflict: A comparison of Hispanic immigrants and non-immigrants", Cross Cultural Management: An International Journal, Vol. 21 Issue: 3, pp.306-325, https://doi.org/10.1108/CCM-01- 2013-0002

Davis, K. D., Gere, J., \& Sliwinski, M. J. (2017). Investigating the work-family conflict and health link: Repetitive thought as a mechanism. Stress Health, 33, 330-338. https://doi.org/10.1002/smi.2711

Dormann, C., \& Zapf, D. (1999). Social support, social stressors at work and depressive symptoms: Testing for main and moderating effects with structural equations in a three-wave longitudinal study. Journal of Applied Psychology, 84, 874-884.

Eagle, B.W., Miles, E.W., \& Icenogle, M. L. (1997). Interrole conflicts and the permeability of work and family domains: Are there gender differences? Journal of Vocational Behavior, 50, 168-184. 
Ford, M.T., Heinen, B.A., \& Langkamer, K.L. (2007). Work and family satisfaction and conflict: a meta-analysis of cross-domain relations. Journal of Applied Psychology, 92 (1), 57-80.

Frone, M.R, Russell. M \& Cooper. M.L, (1992). Antecedents and outcomes of work-family conflict: testing a model of the work-family interface, Journal of Applied Psychology, 77(1), Pages 65-78

Frone, M. R. R., Russell, M., \& Cooper, M. L. (1992). Prevalence of work-family conflict: Are work and family boundaries asymmetrically permeable? Journal of Organizational Behavior, 13, 723-729.

Frone, M.R., Yardley, J.K., \& Markel. K.S. (1997). Developing and testing an intergrative model of the work family interface. Journal of Vocational Behavior. 50, 145-167.

Fu, C.K., \& Shaffer, M.A. (2001). The tug of work and family: direct and indirect domain-specific determinants of work-family conflict. Personnel Review, 30, 502522.

Gao, Y., Shi, J., Niu, Q., \& Wang, L. (2013). Work-Family Conflict and Job Satisfaction: Emotional Intelligence as a Moderator. Stress and health : Journal of The International Society For The Investigation Of Stress. 29. 10.1002/smi.2451.

Grandey, A. A., Cordeiro, B. L., \& Crouter, A. C. (2005). A longitudinal and multi-source test of the work-family conflict and job satisfaction relationship. Journal of Occupational and Organizational Psychology, 78, 305-323.

Greenhaus, J.H. \& Beutell, N.J. (1985). "Sources of conflict between work and family roles", Academy of Management Review, 10, 76-88.

Greenhaus, J.H., \& Powell, G.N. (2006). When work and family are allies: a theory of workfamily enrichment. Academy of Management Review, 31 (1), 72-92.

Greenhaus, H.J., Tammy, D.A., \& Spector, P.E. (2006). Health consequences of workfamily: the dark side of the work-family interface. Research in Occupational Stress and Well-Being, 5, 61-98. 10.1016/S1479-3555(05)05002-X.

Green, S, Salkind, N., and Akey, T. (1997) Using SPSS for Windows, Prentice Hall, New Jersey, 1997.

Gruenewald TL, Seeman TE. (2010). Social support and physical health: links and mechanisms. In: Steptoe A, editor. Handbook of behavioral medicine: methods and applications. 1. New York, Dordrecht, Heidelberg, London: Springer. p. 225.

Gutek, B. A., Searle, S., \& Klepa, L. (1991). Rational versus gender role explanations for work-family conflict. Journal of Applied Psychology, 76, 560-568.

Hair, Jr. J.F., Anderson, R.E., Tatham, R.L., \& Black, W.C (2006). Multivariate Data Analysis, $6^{\text {th }}$. Ed. Upper Saddle River, NJ:Prentice Hall.

Hamizatun Akmal, M. Y. \& Norzaini, A. (2013). Perkaitan antara pengurusan masa dan stress dalam kalangan pelajar siswazah di IPTA. AJTLHE, 5(1), 34-39.

Higgins, C. A., Duxbury, L. E., \& Irving, R. H. (1992). Work-family conflict in the dualcareer family. Organizational Behavior and Human Decision Processes, 51, 51-75.

Hsu, Y. R. (2011). Work-family conflict and job satisfaction in stressful working environments: The moderating roles of perceived supervisor support and intern locus of control. International Journal of Manpower, 32(2), 233Y248. doi:10.1108/ 01437721111130224

Kahn, R. L., Wolfe, D. M., Quinn, R., Snoek, J. D., \& Rosenthal, R. A. (1964). Organizational Stress, New York: Wiley

Kanter, R.M. (1977). Men and Women of the Corporation, Basic Books, New York.

Karatepe, O.M., \& Baddar. L (2006). An empirical study of the selected consequences of frontline employees' work-family conflict and family-work conflict, Tourism Management, 27, 1017-1028 
Kelloway, E.K., Gottlieb, B.H. \& Barham, L. (1999). "The source nature and direction of work and family conflict: a longitudinal investigation", Journal of Occupational Health Psychology, 4(4), . 337-46.

Kelly, R. \& Voydanoff, P. (1985). "Work-family role strain among employed parents", Family Relations, 34(3), 367-74.

Kossek, E. E., \& Ozeki, C. (1999). Bridging the work-family policy and productivity gap: A literature review. Community, Work, and Family, 2, 7-32.

Lakey, B., \& Cohen, S. (2000). Social support theory and measurement. In S. Cohen, L. Underwood, \& B. H.Gottlieb (Eds.), Social support measurement and intervention: A guide for health and social scientists (pp. 29-52). New York: Oxford University Press.

Leiter, M. P., \& Schaufeli, W. B. (1996). "Consistency of the burnout construct across occupations". Anxiety, Stress, and Coping (9), 229-243.

Lin, P. Y. (2008). A research for the relationship between work family conflict and job performance of international tourist hotel employees in Taiwan: The moderating effect of social support (Unpublishedmaster'sthesis).ProvidenceUniversity, Taichung City, Taiwan. (Original work published in Chinese)

Montgomery, A.J, Panagopolou. E \& Benos. A.(2006). Work-family interference as a mediator-mediator between job demands and job burnout among doctors, Stress and Health, 22, 203-212

Nabavi, A.H., \& Shahryari, M. (2012). Linkage Between Worksite Support with Work Role Expectation, Role Ambiguity and Its Effects on Work-Family Conflict, Canadian Social Science, 8(4), 112-119.

Nart, S. and Batur, O. (2013). The relation between work-family conflict, job stress, organizational commitment and job performance: a study of Turkish primary teachers. European Journal of Research on Education, 2(2), 72-81.

Netemeyer, R. G., Boles, J. S., \& McMurrian, R. (1996). Development and validation of work- family conflict and family- work conflict scales. Journal of Applied Psychology, 81, 4, 400-410.

Ollier-Malaterre, A., M. Valcour, L. den Dulk and E.E. Kossek (2013) . Theorizing national context to develop comparative work-life research: A review and research agenda. Eur. Manage. J., 31: 433-447.

Parasuraman, S., Greenhaus, J. H., \& Granrose, C. S. (1992). Role stressors, social support, and well-being among two-career couples. Journal of Organizational Behavior, 13, 339-356.

Perry Jenkins, M., Goldberg, A. E., Pierce, C. P., \& Sayer, A. G. (2007). Shift work, role overload, and the transition to parenthood. Journal of Marriage and Family, 69, $123-$ 138.

Posig, M. \& Kickul, J. (2004). Work-role expectations and work family conflict: gender deferences in emotional exhaustion, Women in Management Review, 19, 7, 373-386

Rasli, A.(2006). Data Analysis and Interpretation: A Handbook for Postgraduate Social Scientists, Penerbit Universiti Teknologi Malaysia, Skudai, Johor, Malaysia.

Sekaran, U. (2006). Research Methods for Business, A Skill Building Approach, Fourth Edition, Wiley.

Selvarajan, T. R., Singh, B., \& Cloninger, P. A. (2016). Role of personality and affect on the social support and work family conflict relationship. Journal of Vocational Behavior, 94, 39-56.

Stansfeld SA, Marmot M, Wilkinson R. (2006) Social support and social cohesion. Social determinants of health:;2:148-171. 
Stoner, C. R., Hartman, R.I., \& Arora, R. (1990). Work-home role conflict in female owners of small business: An exploratory study. Journal of Small Business Management, 28, 30-38.

Taylor SE, Seeman TE.(1999) Psychosocial resources and the SES-health relationship. Ann N Y Acad Sci. 896:210-225. doi: 10.1111/j.1749-6632.1999.tb08117.x.

Thomas, L. T., \& Ganster, D. C. (1995). Impact of family-supportive work variables on work- family conflict and strain: A control perspective. Journal of Applied Psychology, 80, 1, 6-15.

Viswesvaran, C., Sanchez, J.I., \& Fisher, J. (1999). The role of social support in the process of work stress: A meta-analysis. Journal of Vocational Behavior, 54(2), 314-334.

Voydanoff, P. (1988). Work role characteristics, family structure demands, and work-family conflict. Journal of Marriage and the Family, 50, 749-761.

Wadsworth,L.L. (2003). The application of role-identity salience to the study of social support and work-family interaction (Unpublished doctoral dissertation). University of Utah, USA.

Weiss, R.S. (1990). Staying the course, The Free Press, New York.

Wang, Y., Liu, L., Wang, J., Wang, L., 2012. Work-family conflict and burnout among Chinese doctors: the mediating role of psychological capital. J. Occup. Health 54 (3), 232240.

Wang, M.-L., \& Tsai, L.-J. (2014). Work-Family Conflict and Job Performance in Nurses. Journal of Nursing Research, 22(3), 200-207.

Yang, C. L., \& Carayon, P. (1995). Effect of job demands and social support on worker stress: A study of VDT users. Behaviour and Information Technology, 14: 32-40.

Zhang. M, Griffeth. R. W \& Fried. D.D, (2012). "Work Family Conflict and Individual Consequences", Journal of Managerial Psychology, 27, No.7. 